\title{
Elimination of Salmonella enterica serovar Typhimurium in artificially contaminated eggs through correct cooking and frying procedures
}

\author{
Eliminação de Salmonella enterica sorovar Typhimurium em ovos contaminados artificialmente por \\ procedimentos corretos de cozimento e fritura
}

\author{
Geovana Dagostim SAVI ${ }^{1}$, Tiago BORTOLOTTO ${ }^{1}$, Lutiana Roque SIMÕES ${ }^{1}$, Tatiana BARICHELLO ${ }^{1 *}$
}

\begin{abstract}
Salmonellosis is a serious foodborne disease associated with the presence of bacteria in eggs or foods containing raw eggs. However, the use of appropriate procedures of cooking and frying can eliminate this contamination. There are few studies on the elimination of contamination of Salmonella in hens' eggs through typical frying procedures, especially for Salmonella enterica serovar Typhimurium (or S. typhimurium). The aim of this study was to determine the appropriate conditions for cooking and frying hens' eggs artificially contaminated with S. typhimurium, making them free of bacterial contamination. Hens' eggs were artificially contaminated with S. typhimurium and subjected to various processes of cooking, frying and food preparation. It was observed that the minimum time necessary to eliminate contamination through cooking procedures is 5 minutes after the water starts boiling, and also that, cooking in the microwave oven complete eliminates the bacterial contamination. When the eggs were fried on both sides, keeping the yolk hard, a complete bacterial elimination was observed. Mayonnaise prepared with vinegar presented a decrease in bacterial colonies when compared mayonese prepared with lemon.
\end{abstract}

Keywords: Salmonella typhimurium; hen's eggs; mayonnaise; eggs cooked; eggs fried.

\section{Resumo}

A salmonelose é uma grave doença de origem alimentar associada à presença de bactérias em ovos ou alimentos contendo ovos crus. No entanto, a utilização de procedimentos apropriados de cozimento e fritura pode eliminar esta contaminação. Há poucos estudos sobre a eliminação da contaminação de Salmonella em ovos de galinha por fritura em procedimentos típicos de cozinha, especialmente para Salmonella enterica serovar Typhimurium (S. typhimurium). O objetivo deste estudo foi verificar as condições apropriadas, para cozinhar e fritar ovos de galinha artificialmente contaminados por S. typhimurium, necessárias para torná-los livres de contaminação. Os ovos de galinha foram contaminados artificialmente por S. typhimurium e submetidos a vários processos de cozimento, fritura e preparação. Observou-se que o tempo mínimo necessário para eliminar a contaminação com o procedimento de cozimento é de 5 minutos após a fervura da água e que o cozimento no forno microondas eliminou a contaminação bacteriana. Com o procedimento de fritura, somente estão livres de contaminação os ovos fritos em ambos os lados mantendo a gema dura. Na preparação das maioneses, a maionese preparada com vinagre apresentou uma diminuição das colônias bacterianas quando comparada a maionese preparada com limão.

Palavras-chave: Salmonella typhimurium; ovos de galinha; maioneses; ovos cozidos; ovos fritos.

\section{Introduction}

Salmonellosis is a foodborne disease caused by the consumption of contaminated food by Salmonella species (MEAD et al., 1999; SCHROEDER et al., 2005). Salmonella is a well-documented pathogen known to occur in a wide range of foods, especially poultry products (RIVOAL et al., 2009). The most incriminated foods are poultry meat and fresh eggs (OLIVEIRA; SILVA, 2000; PERESI et al., 1998). In most cases, the salmonellosis is caused by $S$. enteretidis contamination, but Salmonella enterica serovar Typhimurium (also known as S. typhimurium) can also provoke this disease (GUARD-PETTER, 2001). The enteric infections due to S. typhimurium and other Salmonella species develop gastrointestinal infection, with symptoms such as abdominal pain, diarrhea, low fever and vomiting (SHINOHARA et al., 2008).
Salmonellosis represents a significant cost to society in many countries and few countries report the data on economic cost of the disease. In the USA, there are estimates of 1.4 million non-typhoidal Salmonella infections resulting in 15,000 hospitalizations and 580 deaths annually. The total cost associated to Salmonella is estimated at US\$ 3 billion annually in the United States (WORLD..., 2009). 1,195 outbreaks of Salmonella were reported in Brazil in 2007, with $22.6 \%$ of them being provoked by the consumption of foods with raw eggs (CARMO, 2009).

Fresh eggs contamination by Salmonella species can be due to two possible mechanisms: contamination on the outer shell surface and internally. Internal contamination can be the result of penetration through the eggshell or by direct contamination

Received 23/9/2009

Accepted 6/12/2009 (004423)

${ }^{1}$ Laboratory of Experimental Microbiology, Postgraduate program in Health Sciences, University of Southern Santa Catarina - UNESC, Av. Universitária, 1105, CEP 88806-000, Criciúma, SC, Brazil,E-mail: tba@unesc.net

${ }^{*}$ Corresponding author 
of egg contents before oviposition, originating from infection of the reproductive organs. This is considered to be the major route of egg contamination and it should be controlled by applying sanitary measures at the breeders level (hygiene practices and eventually vaccination). External contamination can be reduced by preventing contacts between the laying hens and by cleaning and disinfecting the flock's environment (GANTOIS et al., 2009). Salmonella is known for its ability to asymptomatically infect the hen's oviduct (DE BUCK et al., 2004; NAMATA et al., 2004). It has not yet been clarified which route of contamination is the most important, but studies show that $S$. enteritidis is capable of penetrating the egg shell and subsequently reach the egg yolk (TODD, 1996; SCHOENI et al., 1995).

In Brazil, there are some reports confirming the presence of Salmonella species on the surface of egg shell and yolk, and in other food products commercially avaliable in markets (OLIVEIRA; SILVA, 2000; PERESI et al., 1998). The consumption of raw or slightly cooked eggs (in mousse, mayonnaise, beverages and other foods) contributes to an increase of the salmonellosis rate (RADFORD; BOARD, 1993; LOCK; BOARD, 1995), being necessary an incorporation of hygiene and disinfecting measures in the technology of fresh egg production (SCHOENI et al., 1995; MURCHIE et al., 2008). The risk of microbial contamination is minimal for hard-boiled eggs, but medium and certainly soft-boiled eggs are a potential risk factor for salmonellosis. The inactivation of $S$. enteritidis in eggs by boiling depends on the initial temperature of the egg. However, after 10 minutes of boiling, all $S$. enteritidis contamination is eliminated, independent of the initial temperature of the egg (GRIJSPEERDT; HERMAN, 2003).

Although there are many reports about the elimination of Salmonella contamination in eggs by boiling, there is a lack of studies on its elimination by frying and other types of cooking procedures, especially for $S$. typhimurium. Therefore, the aim of this study was to investigate the proper conditions to boil and fry S. typhimurium artificially contamined eggs and to evaluate the time of boiling and the frying procedure.

\section{Materials and methods}

\subsection{Eggs source}

Hens' eggs were obtained commercially and inspected. All the eggs with cracked shells or contaminated with feces were discarded. Prior the the experiments, the eggs were submerged in ethanol $70 \%(\mathrm{v} / \mathrm{v})$ for 30 seconds and cleaned with a sterile towel to decrease the chance of external contamination (PERESI et al., 1998). Fifty eggs were selected and used to determine the average yolk weight $(12.78 \mathrm{~g})$ and also to confirm any prior Salmonella contamination as described in 2.3. Experimental work was started on the day the eggs were obtained and all procedures were carried out in room temperature.

\subsection{Preparation of inoculum}

A S. typhimurium (ATCC 14028) sample was grown overnight at $37{ }^{\circ} \mathrm{C}$ in Salmonella-Shigella media (Himedia). After the incubation, some colonies of the culture were diluted in a sterile saline solution $(\mathrm{NaCl} 0.9 \%)$ up to $0.5 \mathrm{McFarland}$ standard, to obtain a bacterial cell density around $10^{8} \mathrm{CFU} \cdot \mathrm{mL}^{-1}$ $\left(\mathrm{OD}_{600}=0.110\right)$ and diluted to $10^{6} \mathrm{CFU} \cdot \mathrm{mL}^{-1}$. Then, $100 \mu \mathrm{L}$ of the suspension $\left(10^{6} \mathrm{CFU} \cdot \mathrm{mL}^{-1}\right)$ was inoculated with a needle $(25 \times 48 \mathrm{~mm})$ connected to $1 \mathrm{~mL}$ syringe into each egg at the 2 o'clock position in an approximately parallel path. The final bacterial concentration was approximately $10^{4} \mathrm{CFU} . \mathrm{g}^{-1}$ of yolk (PERESI et al., 1998; NAMATA et al., 2004; MURCHIE et al., 2008). The position and size of the syringe was previously confirmed inoculating $100 \mu \mathrm{L}$ of gentian violet, instead of the inoculum, in three eggs and breaking them into Petri dishes to visualize the presence of the dye in the yolk (COGAN et al., 2001). For each inoculation, the plunger of the syringe was drawn back to confirm that the needle had reached the yolk. Each hole was covered with quick-drying sterile adhesive, immediately after inoculation, to prevent external contamination. Eggs inoculated with the bacterial suspension were kept for 3 days at $25^{\circ} \mathrm{C}$ to promote the S. typhimurium growth and the subsequent yolk contamination.

\subsection{Cooking eggs procedures}

The artificially contaminated eggs were used in six cooking procedures in triplicates. Twelve them were cooked in a sterile becker with $200 \mathrm{~mL}$ of water for 0 (control), 3, 5 and 10 minutes after the water stared to boil. After the cooking, each egg was opened aseptically and the yolk was removed with a sterile spatula and transferred to a sterile Petri dish. The last 6 eggs were placed in sterile Petri-dishes. The eggs were aseptically broken and cooked in microwave oven for 40 or 60 seconds.

The verification of $S$. typhimurium contamination was carried out by removing a portion of the yolk, with the aid of bacteriological loop of one microliter, and inoculating it on Salmonella-Shigella media, being incubated for 24 hours at $37^{\circ} \mathrm{C}$ in a bacteriological incubator. After incubation, the presence of colonies was counted in a colony counter and expressed as $\log \left(\mathrm{CFU} \cdot \mathrm{mL}^{-1}\right)$.

\subsection{Preparation of mayonnaise}

Nine artificially contaminated eggs were used in three different mayonnaise preparations in triplicates. The eggs were broken aseptically and the raw yolks were transferred to a sterile becker. Around $100 \mathrm{~mL}$ of olive oil were added to the yolks and the mixtures were homogenized to get a creamy aspect. $2 \mathrm{~mL}$ of vinegar, lemon juice or water (control) were also added to the final mixture and homogenized again for at least 2 minutes. The verification of $S$. typhimurium contamination was carried out as described in 2.3 .

\subsection{Eggs frying procedures}

Fifteen contaminated eggs were used in five frying procedures in triplicates. The contaminated eggs were broken aseptically and fried in a frying pan following procedures below: one side of the egg fried, keeping the yolk soft (procedure 1); both sides fried, keeping the yolk soft (procedure 2); one side of the egg fried, keeping the yolk hard (procedure 3); both sides fried, keeping the yolk hard (procedure 4); and not fried (as 
serve as control, procedure 5). The verification of S. typhimurium contamination was carried out as in 2.3 .

\subsection{Statistical analysis}

Statistical analysis of the results was performed by variance analysis (ANOVA) completed with the post-hoc Tukey's test. For this, GraphPad Prism 5.0 (GraphPad Inc. San Diego, CA, USA) was used, accepting the level of significance of $p<0.05$.

\section{Results}

The elimination of $S$. typhimurium by cooking procedure in different times of boiling is shown on Figure 1. Before the cook procedure ( 0 minute), the contamination estimated in log $\left(\mathrm{CFU} . \mathrm{mL}^{-1}\right)$ was $6.51 \pm 0.55$. After 3 minutes the $\log \left(\mathrm{CFU} . \mathrm{mL}^{-1}\right)$ downs to $3.12 \pm 0.40$, reaching zero after 5 minutes maintaining this condition up to 10 minutes. The curve fitted to observe the effect of the time of boiling on $S$. typhimurium growth show a $\mathrm{r}^{2}=0,92$ and a half-life of 2.35 minutes. This result provided evidences of the efficiency of boiling water to eliminate the bacterial contamination when the cook procedure is realized at least for 5 minutes. The eggs cooked in microwave oven did not present any contamination $\left.\left[\log \left(\mathrm{CFU} \cdot \mathrm{mL}^{-1}\right)\right]=0\right)$ showing a complete elimination of $S$. typhimurium under different times of cooking ( 40 or 60 seconds).

The frying eggs experiments demonstrate a worrying situation as seen in Table 1 . The only procedure that was efficient to significantly eliminate $S$. typhimurium contamination was frying both sides of the egg keeping the hard yolk. All other procedures shows the presence of the bacterial contamination slighter then control but not significant different, except for procedure (1), where the bacterial growth is same as control.

The mayonnaise prepared with contaminated eggs shown a strong bacterial contamination confirming that the preparation of mayonnaise with raw eggs did not able to eliminate a further bacterial contamination (Table 2 ). When vinegar were added to the preparations, the contamination was slight reduced without

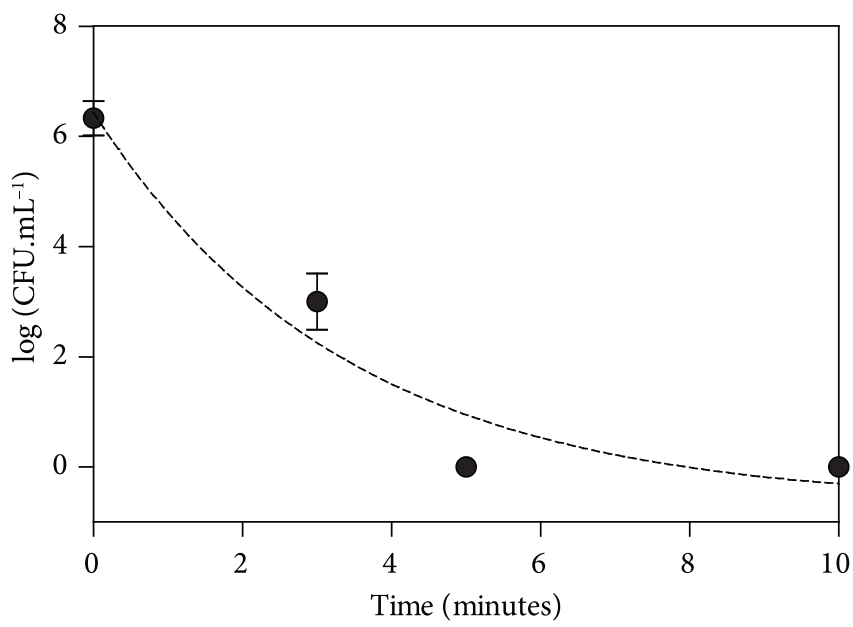

Figure 1. S. tiphymurium growth $\left[\log \left(\mathrm{CFU} \cdot \mathrm{mL}^{-1}\right)\right]$ in artificial contaminated eggs versus time of cooking (minute) by boiling. The points represent de mean \pm standard desviation of the three replicates. The curve fitted show a $\mathrm{r}^{2}=0.92$ and a half-life of 2.35 minutes.
Table 1. S. tiphymurium growth $\left[\log \left(\mathrm{CFU} \cdot \mathrm{mL}^{-1}\right)\right]$ in artificially contaminated eggs under different frying procedures. The values represent the mean \pm standard deviation of three replicates.

\begin{tabular}{lc}
\hline Frying egg procedure description & $\begin{array}{c}\text { S. tiphymurium growth } \\
\left(\log \left(\mathrm{CFU} \cdot \mathrm{mL}^{-1}\right)\right)\end{array}$ \\
\hline One side, keeping the soft yolk (1) & $6.33 \pm 0.87$ \\
Both sides, keeping the soft yolk (2) & $4.95 \pm 0.98$ \\
One side, keeping the hard yolk (3) & $3.60 \pm 1.21$ \\
Both sides, keeping the hard yolk (4) & $0.00 \pm 0.00^{*}$ \\
Not fried (5) & $6.33 \pm 0.31$ \\
\hline${ }^{*} \mathrm{p}<0.05$ versus procedure 5 (not fried) (post-hoc Tukey test).
\end{tabular}

Table 2. S. tiphymurium growth $\left[\log \left(\mathrm{CFU} \cdot \mathrm{mL}^{-1}\right)\right]$ in mayonnaise made with artificial contaminated eggs. The values represent the mean \pm standard desviation of three replicates.

\begin{tabular}{lc}
\hline Mayonnaise procedure description & $\begin{array}{c}\text { S. tiphymurium growth } \\
\left(\log \left(\mathrm{CFU} \cdot \mathrm{mL}^{-1}\right)\right)\end{array}$ \\
\hline With raw egg and water (control) & $6.12 \pm 0.62$ \\
With raw egg and lemon juice & $6.41 \pm 0.88$ \\
With raw egg and vinegar & $6.16 \pm 0.78$ \\
\hline
\end{tabular}

statistical significance. The lemon juice did not have effect on S. typhymurium grown.

\section{Discussion}

Foodborne diseases, such salmonellosis, are the biggest problem of international public health. In almost all cases, salmonellosis is caused by the consumption of foods containing raw or insufficiently cooked eggs (GUARD-PETTER, 2001; GANTOIS et al., 2009; PERESI et al., 1998; MURCHIE et al., 2008; MENSAH et al., 2002), which guarantees the persistence of contamination by Salmonella species. This contamination occurs even when there are low quantities of bacteria in yolk or albumen (HUMPHREY et al., 1991) and mild conditions of temperature, as evidenced by Grijspeerdt and Herman (2003), who reported that $S$. typhimurium growth was satisfactory at $25{ }^{\circ} \mathrm{C}$. This demonstrates the importance of storing eggs at lower temperature, at least at $4{ }^{\circ} \mathrm{C}$, what reduces the excessive growth of microorganisms (PERESI et al., 1998). However, low temperatures do not eliminate bacterial contamination, and the lack of suitable methods of food preparation as well as of material hygiene, may increase the risk of human contamination by Salmonella. Therefore, it is necessary to establish an appropriate cooking time in order to eliminate S. typhimurium in eggs. This study demonstrates that the contamination by $S$. typhimurium in eggs can be eliminated by cooking them for at least 5 minutes after the boiling water point (Figure 1). This result is close to those observed by Schoeni et al. (1995) using S. enteretidis, where the length of cooking observed for total elimination of bacterial contamination was of approximately 6 minutes after the water reached $100{ }^{\circ} \mathrm{C}$ in bunsen burner. Inhibition of bacterial elimination of $S$. typhimurium in eggs when cooked in microwave oven confirmed the effect of microwave in the face of enterobacteria (PAPADOPOULOU et al., 1995).

The results of the mayonnaise preparations show the lack of efficiency of vinegar and lemon juice, which are normally 
added to mayonnaise in some countries, to eliminate the bacterial contamination. These procedures kept the food as a contamination vehicle, when prepared with raw eggs (ANDRADE; NEGRETE; OLIVEIRA, 2002).

The consumption of fried eggs could also lead to contamination by S. typhimurium if the procedure used for frying the egg is inadequate. This work tested several methods of frying eggs and some results were worrying, since the only procedure that was efficient to completely inhibit the bacterial growth was the one where the eggs were fried on both sides keeping the yolk hard. We observed the growth of S. typhimurium in all the eggs the yolk remained soft.. Even in the procedure where the egg was fried on one side and the yolk was kept hard, there was not a complete elimination of S. typhimurium contamination.

Initially, we believed that the condition of the yolk after the process of frying indicated the elimination of S. typhimurium in eggs. However, the results showed that this is not only the condition of yolk (soft or hard), that is an indicator of the elimination of bacterial growth, but also that the area of contact between the egg and the frying pan (fried on one side and fried on both sides) interferes on the process of bacterial elimination. It is believed that, in the procedure of frying the eggs on both sides until the yolk is hard, there is an increase in time and in the field of heat transfer between the frying pan and the egg, what could increase the efficiency of the removal of S. typhimurium, explaining why this procedure is more efficient than the other tested ones.

\section{Conclusions}

We concluded that, in order to have a complete inhibition of growth of the bacterium $S$. typhimurium possibly present in eggs or foods prepared with raw eggs, correct cooking and frying procedures are needed. The time required to eliminate S. typhimurium through the cooking procedure is of at least 5 minutes after the boiling of water, or to cook in microwave oven. Mayonnaise preparations with raw eggs are dangerous, because the bacterial contamination os still present even after the addition of vinegar or lemon juice. The fried eggs are safe from S. typhimurium contamination when they are fried on both sides keeping the yolk hard.

\section{Acknowledgements}

The authors would like to thank CNPq, FAPESC and UNESC for the financial support.

\section{References}

ANDRADE, J. Z.; NEGRETE, I. D. R. A.; OLIVEIRA, T. C. R. M. Evaluation of the cotamination by Staphylococcus aureus and Salmonella spp., of potato salad purchased at restaurants of Londrina, PR. Higiene alimentar, v, 16, p. 62-71, 2002.

CARMO,G. M. I. Vigilância Epidemiológica das Doenças Transmitidas por Alimentos no Brasil. Porto Alegre: ANVISA, 2008. Disponível em: <http://www.anvisa.gov.br/ALIMENTOS/ aulas/i_rcvisa/doencas_brasil_greice.ppt>. Acesso em: 24 jun. 2009.
COGAN, T. A. et al. Growth of Salmonella enteritidis in artificially contaminated eggs: the effects of inoculum size and suspending media. International Journal of Food Microbiology, v. 70, p. 131-41, 2001. http://dx.doi.org/10.1016/S0168-1605(01)00540-2

DE BUCK, J. et al. Tubular glands of the isthmus are the predominant colonization site of Salmonella enteritidis in the upper oviduct of laying hens. Poultry Science, v. 83, p. 352-8, 2004. PMid:15049486.

GANTOIS, I. et al. Mechanisms of egg contamination by Salmonella enteritidis. FEMS Microbiology Reviews, v. 33, p. 718-38, 2009. PMid:19207743. http://dx.doi.org/10.1111/j.15746976.2008.00161.x

GRIJSPEERDT, K.; HERMAN, L. Inactivation of Salmonella enteritidis during boiling of eggs. International Journal of Food Microbiology, v. 82, p. 13-24, 2003. http://dx.doi.org/10.1016/ S0168-1605(02)00246-5

GUARD-PETTER, J. The chicken, the egg and Salmonella enteritidis. Environmental Microbiology, v. 3, p. 421-30, 2001. PMid:11553232. http://dx.doi.org/10.1046/j.1462-2920.2001.00213.x

HUMPHREY, T. J. et al. Number of Salmonella enteritidis in the contents of naturally contaminated hens' eggs. Epidemiology and Infection, v. 106, p. 489-96, 1991. http://dx.doi.org/10.1017/ S0950268800067546

LOCK, J. L.; BOARD, R. G. The fate of Salmonella enteritidis PT4 in home-made mayonnaise prepared from artificially inoculated eggs. Food Microbiology, v. 12, p. 181-6, 1995. http://dx.doi.org/10.1016/ S0740-0020(95)80095-6

MEAD, P. S. et al. Food-related illness and death in the United States. Emerging Infectious Diseases, v. 5, p. 607-25, 1999. PMid:10511517. PMCid:2627714. http://dx.doi.org/10.3201/ eid0505.990502

MENSAH, P. et al. Street foods in Accra, Ghana: how safe are they? Bulletin of the World Health Organization, v. 80, p. 546-53, 2002.

MURCHIE, L. et al. Qualitative exposure assessment for Salmonella spp. in shell eggs produced on the island of Ireland. International Journal of Food Microbiology, v. 125, p. 308-19, 2008. PMid:18556082. http://dx.doi.org/10.1016/j.ijfoodmicro.2008.04.026

NAMATA, H. et al. Salmonella in Belgian laying hens: An identification of risk factors. Preventive Veterinary Medicine, v. 83, p. 323-326, 2004. PMid:17961763. http://dx.doi.org/10.1016/j. prevetmed.2007.09.002

OLIVEIRA, D. D.; SILVA, E. M. Salmonela em ovos comerciais: ocorrência, condições de armazenamento e desinfecção da casca. Arquivo Brasileiro de Medicina Veterinária e Zootecnia, v. 52, p. 655-661, 2000. http://dx.doi.org/10.1590/S010209352000000600017

PAPADOPOULOU, C. et al. Survival of enterobacteria in liquid cultures during microwave radiation and conventional heating. Microbiological Research, v. 150, p. 305-09, 1995.

PERESI, J. T. M. et al. Surtos de enfermidades transmitidas por alimentos causados por Salmonella enteritidis. Revista de Saúde Pública, v. 32, p. 477-83, 1998. http://dx.doi.org/10.1590/S003489101998000500011

RADFORD, S. A.; BOARD, R. G. Review: Fate of pathogens in homemade mayonnaise and related products. Food Microbiology, v. 78, p. 269-78, 1993. http://dx.doi.org/10.1006/fmic.1993.1031

RIVOAL, K. et al. Use of pulsed-field gel electrophoresis to characterize the heterogeneity and clonality of Salmonella serotype enteritidis, typhimurium and Infantis isolates obtained from whole liquid eggs. International Journal of Food Microbiology, v. 15, p. 180-6, 2009. http://dx.doi.org/10.1016/j.ijfoodmicro.2008.11.021 
SCHOENI, J. L. et al. Growth and penetration of Salmonella enteritidis, Salmonella heidelberg and Salmonella typhimurium in eggs. International Journal of Food Microbiology, v. 24, p. 385-96, 1995. http://dx.doi.org/10.1016/0168-1605(94)00042-5

SCHROEDER, C. M. et al. Estimate of illnesses from Salmonella enteritidis in eggs, United States, 2000. Emerging Infectious Diseases, v. 11, p. 113-5, 2005.

SHINOHARA, N. K. S. et al. Salmonella spp., importante agente patogênico veiculado em alimentos. Ciência \& Saúde Coletiva, v. 13 , p. $1675-83,2008$. http://dx.doi.org/10.1590/S141381232008000500031

TODD, E. C. D. Risk assessment of use of cracked eggs in Canada. International Journal of Food Microbiology, v. 30, p. 125-43, 1996. http://dx.doi.org/10.1016/0168-1605(96)00995-6

WORLD HEALTH ORGANIZATION - WHO. Drug-resistant Salmonella. 2005. Disponível em: <http://www.who.int/mediacentre/ factsheets/fs139/en/>. Acesso em: 24 jun. 2009. 